\title{
'To fish or not to fish?': fishing communities of Arctic Yakutia in the face of environmental change and political transformations
}

\author{
Stanislav Ksenofontov and Norman Backhaus \\ Department of Geography, University of Zurich, Winterthurerstrasse 190, 8057 Zurich, \\ Switzerland (stanislav.ksenofontov@geo.uzh.ch,norman.backhaus@geo.uzh.ch)
}

\section{Gabriela Schaepman-Strub}

Department of Evolutionary Biology, University of Zurich, Winterthurerstrasse 190, 8057 Zurich, Switzerland

\section{Received November 2016; first published online 3 May 2017}

ABSTRACT. This paper assesses the vulnerability of Arctic fishing communities. We hypothesise that climate change related trends, such as increasing temperature and altered seasonality, and shocks, such as the breakdown of the Soviet Union or new fishing regulations, increase vulnerability of local Arctic peoples and compromise the sustainability of their livelihoods. Research shows that over recent decades local people have observed environmental changes and a significant decrease in the number of fish caught. Fishing regulations introduced after the collapse of the Soviet Union burdened fishers with quotas and temporal limitations that have hindered their fishing activities. While the adaptability of traditional fishing techniques to seasonally changing conditions might indicate the potential to adapt to future conditions under climate change, fishing regulations appear to limit this potential to adapt.

\section{Introduction}

Climate warming in the Arctic is more intense than in any other region of the planet (ACIA, 2005; AMAP, 2012). As a result northern terrestrial and aquatic ecosystems are experiencing profound changes, which impact the natural resources of local people (Callaghan et al., 2011). Local people of Arctic Yakutia in northeastern Siberia have for centuries been highly dependent on the natural resources which they have collected as fishers, hunters, gatherers and reindeer herders (Alekseeva, 2012; Nuttall et al., 2005).

Climate change is expected to have an impact on Arctic fish populations, and they are likely to face much larger changes than those in tropical regions (Ficke, Myrick, \& Hansen, 2007). Many Yakutian fish species tend to shift northwards as a response to climate change. Several species in the Lena River may migrate to the estuary, which is stocked mainly with whitefish and char. This results in elevated competition between local Arctic fish species and newcomers. As a consequence, populations of native species may become depleted by northward migrating predators (Ficke et al., 2007). Furthermore, increased temperatures may cause higher rates of bacterial diseases in aquatic ecosystems (Hefer \& Pruginin, 1981; Wedemeyer, 1996). It is known that white fish in the lower courses of the Lena and Indigirka rivers have been infested by 12 types of parasites (Kokolova et al., 2012).

In addition to climate-induced changes in the abundance of natural fish resources, the livelihoods of local Arctic communities are affected by other factors such as the collapse of the Soviet Union, changing fishing and hunting regulations, depopulation and the challenges of living in remote areas (West \& Hovelsrud, 2010). Furthermore, high rates of unemployment $(75-80 \%)$ have in- creased their dependence on natural resources (Lavrillier, 2013).

This paper attempts to assess the vulnerability context (Carney, 2003; DFID, 2002) of these communities, both indigenous and non-indigenous. We hypothesise that trends, such as climate change, and shocks, such as the breakdown of the Soviet Union or the introduction of new fishing regulations, increase Arctic peoples' vulnerability and compromise the sustainability of their livelihoods. Hence, we aim to understand which of the abovementioned stressors impact on the livelihoods of local people and increase their vulnerability. Moreover, we attempt to find out whether and how adaptive strategies adopted by the Arctic communities are appropriate to cope with the pressures. The assumptions and hypotheses are tested using qualitative and quantitative interviews performed in two Arctic regions of the Republic of Sakha (Yakutia). First, we describe impacts of climatic and environmental change on the Arctic communities in the Republic of Sakha (Yakutia), fish species, fishing practices and livelihoods as perceived by the local people. Second, we will draw attention to the effects of political and institutional change on the livelihoods of local populations of Arctic Yakutia. Third, the study assesses and discusses the social and economic impacts of changing fishing regulations and how they influence potential to adapt to future climate impacts.

\section{Climate change, fish and political transformations}

\section{Impact of climate change in Arctic Yakutia}

Investigations into the impacts of climate change on fish and subsistence fisheries have been conducted in Arctic regions (AMAP, 2012; Hendriksen \& Jørgensen, 
2015; Jeffries, Overland, Brown, Mudryk, \& Luojus, 2015; Moerlein \& Carothers, 2012; Nuttall et al., 2005; Prowse et al., 2006; Reist et al., 2006). However, little is known about the situation regarding fish in the Yakutian Arctic.

Shadrin (2009) reported the difficulties faced by two fishing families when lakes in the village of Andryushkino in north Yakutia dried out. Thawing permafrost caused the lake to shrink and as a result, these families were left without their traditional food (Shadrin, 2009). Mustonen (2011), in his research in the northern Yakutian district of Lower Kolyma, also noted that many lakes had shrunk resulting in reduced fish numbers. Consequently, fishing is no longer possible in these areas. Furthermore, the timing of freezing and the break-up of the ice have changed, so ice roads have become dangerous for hunting and herding during the traditional hunting seasons in spring and autumn (Mustonen, 2011).

\section{Fish: more than food}

Fish is a crucial biotic resource for the local Arctic people. Fish is important not only as food, but also as an income source (Caulfield, 2000). Moreover, fish plays an important role in the social fabric of the local people. Fish species consumed and traded by local people include Siberian white salmon (Stenodus leucichthys nelma), Siberian cisco (Coregonus sardinella), Arctic cisco (Coregonus autumnalis) and muksun (Coregonus muksun) (Kirillov, 2002, 2007), and many other species that seasonally migrate from marine to freshwater ecosystems (Nuttall et al., 2005). Fishery is the most important income producing industry in the region. Yakutian fishers are associated to obshchinas - 'self-organised indigenous communities recognised under Russian Federal Law' (Mustonen, 2011, p. 3) - as small-scale fisheries to trade fish on markets in the capital city Yakutsk or to sell to bigger enterprises. These obshchinas provide $73 \%$ of the whole catch for Yakutia. For most Arctic people, fishing is the only source of subsistence and employment (Totonova \& Sleptsov, 2014). In addition to small-scale fisheries, Russian legislation defines six other types of fishing practices, two of which are employed by local Arctic people: indigenous communities practice traditional fishing for subsistence purposes, and non-indigenous individuals are allowed to exercise amateur and sport fishing. In this paper, we will focus on small-scale fisheries (obshchinas) and traditional fishing.

Fishers employ different fishing techniques, depending on the season and related conditions (Sirina, 2012; Tugolukov et al., 1997; Ziker, 2002):

- Ice fishing with nets, where nets are put through holes after the ice freeze-up in October.

- Winter fishing under the ice with a short rod that is lowered through a hole in the ice.

- Spring thin-ice fishing, where, in April and May, nets with small $25 \mathrm{~mm}$ cells are lowered through holes that are drilled in the ice. Spring thin-ice fishing occurs in the upper drainage of a river on thin ice that forms during the winter under the pressure of snow.

- Open water net fishing, where nets are used on the open water after the ice break-up in early summer until the river freezes in late September. Only nets of a certain length (maximum $25 \mathrm{~m}$ ) can be used for this type of fishing according to regulations.

- Seine (nevod) fishing, where a U-shaped dragnet is used during the summer.

In the Allaikhovsky region, for example, fishing is organised into two processes: (1) landing, freezing and storing at the fishing grounds; and (2) collection and transportation from the fishing grounds to the reception station, located in the capital, Chokurdakh. Landing occurs 10$250 \mathrm{~km}$ down and upstream of the Indigirka River, $180 \mathrm{~km}$ from Chokurdakh, $140 \mathrm{~km}$ along the Allaikha River and $480 \mathrm{~km}$ along the Elon River. Timely transportation to the reception centre is not possible in summer because delivery is by motor boat, which is the most expensive part of the industry (Investment Passport, 2015). From the reception centre fish is delivered to Yakutsk either by airplane or truck on ice roads in winter. This is tremendously expensive due to high transportation rates (55 rubles (ca. 1 US\$) per $\mathrm{kg}$ ) and lack of year-round road access (Regnum, 2016). As a result fish in Yakutsk markets is extremely expensive. There was only one fish processing plant in the region, built in 2011 and which, for unknown reasons, did not even operate until it burnt down in January 2017. However, in recent years the Yakutian government has launched various programmes to support Arctic fishers. It compensates $90 \%$ of expenses for refrigeration and freezing equipment, as well as reimburses fishers' expenditure for fishing (Regnum, 2016). In 2015, it allocated 65 million rubles for the modernisation of the fisheries industry. Fishing bases, modular fish primary processing plants and refrigerator containers have been purchased in Arctic regions, including our research sites (AGiP, 2015).

An important element of harvesting natural resources for local people is nimat - 'distribution of equal shares of spoils of the hunt among the whole local community' (Forsyth, 1989, p. 76). According to this custom, any spoil is subject to compulsory equal distribution among all families of a campsite (that is a hunting or fishing party), including families of neighbouring camps (Tugolukov et al., 1997). Anisimov (1936) describes nimat:

'when a hunter kills an animal, he should announce this to a camp member. Then a body of hunters selects a person - receiver of nimat - normally the poorest family of the camp. This person then equally distributes the spoil among all families of the camp. Nimat can be applied not only to animals and birds, but also to fish' (Anisimov, 1936, pp. 76-77).

Offenses against this custom would make Buga (the spirit of the biophysical environment) angry and cease to bring luck (Lavrillier, 2013). It is a traditional practice to establish social relations with individuals, nature and 
spirits in order to support livelihoods and to extend the family. It offers the possibility of marriage as a result of mutual land use by community members, strengthens territorial and economic relations between nomads, and offers a means for the construction and support of ethnic identity. However, today various environmental and climatic changes, processes of urbanisation and globalisation, and related socio-economic changes have seriously challenged the custom of nimat (Sirina, 2012). Over the last five years, due to a decline in animal species, sharing rules have been changed and nimat tends to occur only among family members rather than neighbours, relatives and close friends as it used to. Today nimat is becoming more profit oriented in the context of a market economy. Some households even stopped employing the custom of nimat for economic reasons, selling the whole catch and earning some money to be able to purchase food and goods (Lavrillier, 2013).

\section{Political and institutional change}

Arctic communities have for centuries been resilient and able to adapt to a slowly changing climate owing to their traditional knowledge. However, when it comes to drastic political, economic and other institutional transformations their livelihoods are more vulnerable (Hendriksen \& Jørgensen, 2015). If we follow the Russian history of the twentieth century we can define five major events where Arctic communities were significantly affected by political, economic and institutional change: (1) the policy of collectivisation in the 1930s; (2) the policy of 'forced sedenterisation of nomadic families' (Klokov \& Khrushchev, 2010) in the 1950s; (3) the campaign against so-called 'unpromising villages' in the 1950s and 1960s; (4) the Russification of the education system during the 1950s (Vakhtin, 1992); and (5) the collapse of the Soviet regime in 1991.

The latter brought new challenges to the livelihoods of millions of citizens, especially those practicing a traditional way of life. The break-up of the Soviet Union brought about a change in the economic activities of local people as they adapted to the new market economy (Davydov, 2014). State-run fishing and hunting companies were hamstrung after the termination of central subsidies; therefore, local communities had to fall back on their own experience and relations with others (Ziker, 2002). The transition to a market economy inaugurated the establishment of new regulations by the Russian government associated with subsistence practices. Since 2004, fishing has been restricted by quotas and closed seasons, as well as by type, quantity and size of fishing gear (Article 26, Federal Law No. 166-FS on fishery and the protection of water biological resources, 2004), without taking into account local contexts (Nakhshina, 2012). These processes increase physical, social and cultural vulnerabilities of the Arctic societies, which in turn may affect the sustainability of their livelihoods.

In summary, the fishing communities of Arctic Yakutia are facing significant challenges as a result of not only climatic and environmental fluctuations and trends, but also political and economic transformations.

\section{Theoretical background, methods and research area}

\section{Vulnerability and livelihoods}

Due to the harsh climate and their remoteness local Arctic people have difficult livelihoods in general. Consequences of global change may increase the vulnerability of their livelihoods (Cannon \& Müller-Mahn, 2010). The sustainable livelihoods approach (SLA) is a tool used to examine people's livelihoods in a holistic way. It highlights (poor) people's conditions of life, their opportunities and ability to gain well-being, their vulnerability, resilience and livelihood resources, as well as the institutions in which their livelihoods are embedded (Chambers \& Conway, 1992).

'A livelihood comprises the capabilities, assets (including both material and social resources) and activities required for a means of living. A livelihood is sustainable when it can cope with and recover from stresses and shocks, maintain or enhance its capabilities and assets, while not undermining the natural resource base' (Chambers \& Conway, 1992, p. 6).

Livelihood resources of Arctic people imply material assets, such as natural (that is, reindeer, fish, berries), physical (roads, snow mobiles) and financial, as well as non-material resources, such as human (traditional knowledge, health) and social (kinship, customs) (Carney, 2003; DFID, 2002). Current livelihood strategies (for indigenous people) encompass flexibility towards the availability of fish stocks, their mobility (change of fishing grounds, migration patterns), but also diversification (involvement in different economic sectors, change of consumption habits), and modification of fishing tools (Allison \& Ellis, 2001; Scoones, 1998). Assets and livelihood strategies are affected by the political, environmental and socioeconomic context in which people live. Critical factors that impact on the sustainability of livelihoods, on the one hand, are vulnerability, which means people's susceptibility to an unstable ecological, social, economic or political setting, as well as organisational and institutional contexts (including policies, regulations and rules) (Rakodi, 2002). Sustainable livelihood strategies result in outcomes, which refer to improved material or non-material well-being (that is, income, health) as well as reduced vulnerability (food security, sustainable use of natural resources) (DFID, 2002). Moreover, the framework helps to grasp how transforming regulations and policies will affect local people's livelihoods. Furthermore, it helps in understanding the strategies these communities are adopting to cope with external shocks and transformation processes in order to increase the sustainability of their livelihoods and their well-being.

Even though the sustainable livelihood framework (SLF), as initially defined by DFID, provides a good checklist for the assessment of people's livelihoods and 
their institutional situation, it has been criticised for being power blind and a-historical (for example, de Haan \& Zoomers, 2005; Geiser Müller-Böker, Shahbaz, Steimann, $\&$ Thieme, 2011). While using SLA as an entry point for the purpose of this study, we are conscious of its problems and shortcomings. Therefore, we try to avoid the traps (Geiser et al., 2011) of the SLF and use the livelihood framework more broadly as an approach (SLA) that accommodates power relations and historicity in order to aptly assess vulnerabilities.

\section{Methods}

In order to assess our assumptions and test our hypotheses, and to better understand Arctic livelihoods, their vulnerability to climate and institutional change, two methodological approaches were used in four Arctic settlements: 34 qualitative in-depth interviews with indigenous inhabitants were carried out in 2014 and a quantitative standardised questionnaire with 204 local residents in 2015. In 2015, one of the villages could not be reached because of an unexpected early ice breakup that made transportation over land and on rivers impossible (helicopter transport was not possible). Before conducting interviews, meetings were held with local municipality members in order to gain an overview of the research site as well as to select indigenous interviewees. We identified five categories of stakeholders: officials from local municipalities, key informants (that is, fishers, hunters, reindeer herders), young people, elders and public sector workers. Age distribution was planned to start from 18 years, but as a result of summer vacations and general absence of the 18-26 age group, interviewees were between 27 and 84 years of age. Interviews involved male and female members of local indigenous communities - Eveny, Evenki and Sakha (according to the Russian definition Sakha are not indigenous, whereas they counted as indigenous according to international standards). Interviews - that followed standard guidelines with defined topics but tried to leave space for the respondents to choose their own pace and direction - addressed the following topics: subsistence activities of local people, perceptions of their environment and of the climatic and environmental changes in the area, as well as observed impacts of the climatic and environmental changes, and finally the influence of governmental regulations. The quantitative questionnaire, which mainly addressed fishing, was carried out face-to-face to avoid misunderstandings and to ensure all questions were answered. Respondents of different ethnic (not only indigenous but also local Russian, Ukrainian and others) and age groups were randomly selected. The questionnaire included Likert scale answers regarding agreement to a statement, frequencies, as well as yes/no and open questions. Moreover, selected expert interviews and participatory observation were carried out in the region, various community events were attended, and some relevant grey literature and documents were collected. Interviews and questionnaires were conducted in Sakha or Russian depending on respondents' language proficiency and preference. Digital audio recordings of the interviews were made in order to reduce the risk of having inaccurate or incomplete data. The recordings were then transcribed and analysed in MAXQDA software, in which transcripts were coded into categories in order to compare the data within these groups. Quantitative data was analysed using SPSS. In addition to analysing frequencies, we looked at differences between men and women, indigenous and non-indigenous people, and respondents who had lived for more than or less than 20 years in the area. We regard the different points of the Likert scale as equidistant intervals (for a discussion see Brown, 2011); therefore, we are able to test for significant differences using the Mann-Whitney $U$ test (for non-interval answers a Wilcoxon test was used).

\section{Arctic communities and research area}

This study is based on two case study areas in northeastern Siberia in the Russian Republic of Sakha (Yakutia), where Evenki and Eveny - both part of the Tungus ethnic group - and Sakha live (Fig. 1).

The case study areas are located in four Arctic settlements of Chokurdakh and Olenegorsk in the Allaikhovsky ulus (district), and Tiksi and Kyusyur in the Bulunsky ulus of the Republic of Sakha (Yakutia), northeastern Siberia, Russia. These settlements are located in the deltas of two large rivers: Tiksi and Kyusyur are on the Lena River at the Laptev Sea, Chokurdakh and Olenegorsk are on the Indigirka River at the East Siberian Sea. Chokurdakh $\left(70.6^{\circ} \mathrm{N} .147 .8^{\circ} \mathrm{E}\right)$ is located on the cape of Chokuur Taas (Flinty Stone), on the left bank of the Indigirka River. It is surrounded by Arctic tundra with abundant wildlife. It is an administrative centre of the Allaikhovsky district with a population of 2,068 people. Chokurdakh is an important air and river port. The site is populated by both indigenous and non-indigenous people who are mainly employed in fishing (Nasledie Sela, n.d.; Rosstat, 2016). Olenegorsk $\left(69.8^{\prime \prime} \mathrm{N}, 147.5^{\prime \prime} \mathrm{E}\right)$ is situated on the right bank of the Indigirka River. The area is classified as sub-Arctic taiga. Olenegorsk is a village with a population of 237 people, mainly of indigenous origin: Eveny, Yukagirs, Evenki and Chukchees. The main activities of the villagers include reindeer herding, hunting and fishing (Rosstat, 2016; YuNN, n.d.). Tiksi $\left(71.6^{\circ} \mathrm{N}\right.$, $128.8^{\circ} \mathrm{E}$ ) is the capital of the Bulunsky district and is the northernmost town of Yakutia. The town is surrounded by Arctic tundra. It is an air and sea port. Tiksi was founded as one of the ports of the Northern Sea Route. The population of Tiksi is 4,556 (Rosstat, 2016), both indigenous and non-indigenous, who are employed by the sea port, airport, meteorological station, reserve, among others. Kyusyur $\left(70.6^{\circ} \mathrm{N}, 127.2^{\circ} \mathrm{E}\right)$ is an ethnic village on the right bank of the Lena River, $120 \mathrm{~km}$ from Tiksi. It is dominated by sub-Arctic taiga. The population of Kyusyur is 1,272, mainly indigenous people (Rosstat, 2016). The economy of the village is based on agriculture, but the locals are also involved in fishing, hunting and reindeer herding. The selected areas are diverse because of 


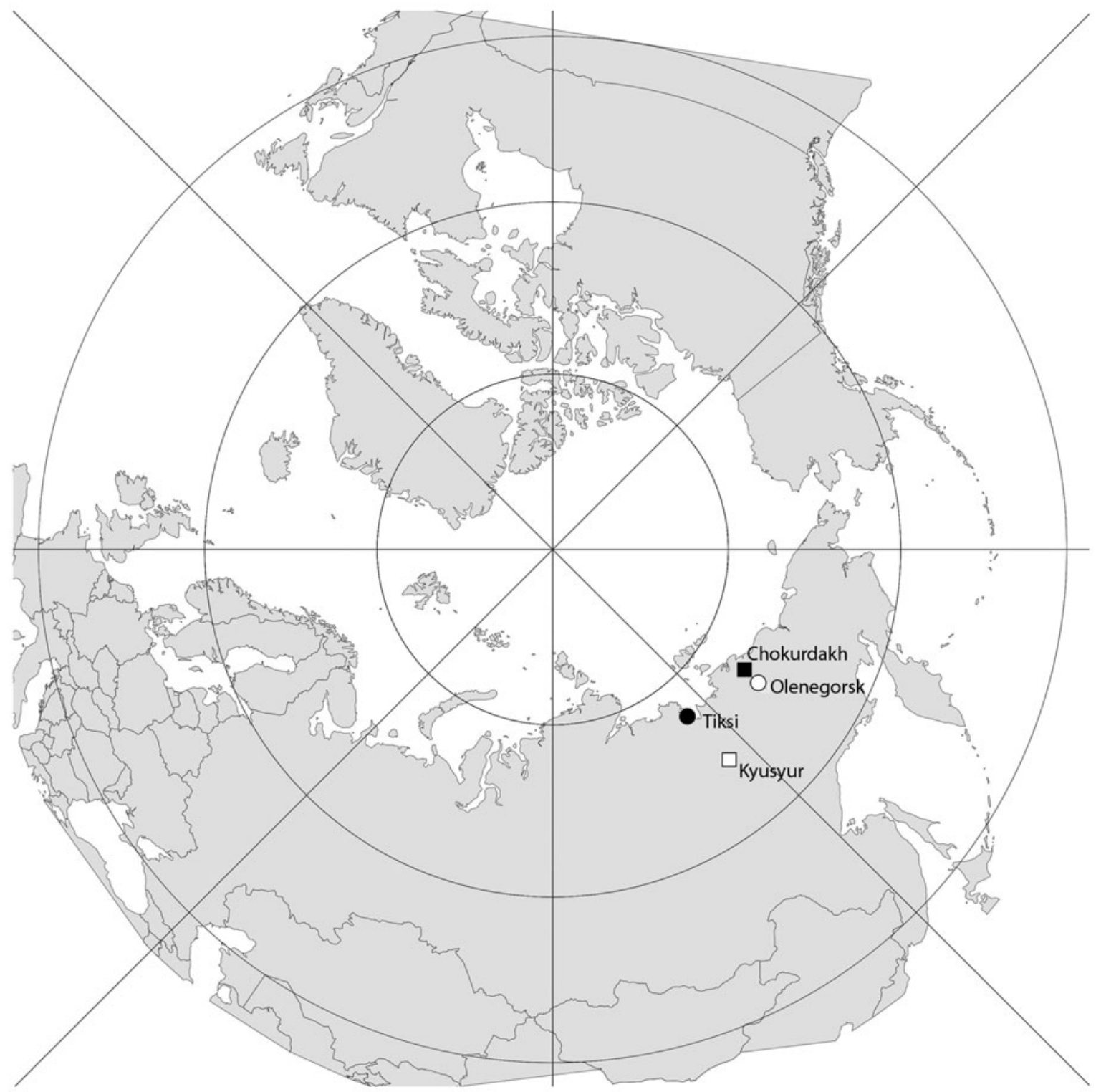

Fig. 1. Location of the study sites in the Russian Republic of Sakha (Yakutia) (map by F. Gerber).

varying levels of industrialisation; therefore, environmental and climatic change have different impacts on people's livelihoods.

Indigeneity is a contested issue in Russian legislation. Officially, it includes small-numbered ethnic groups with populations of less than 50,000 people whose traditional activities are hunting, trapping, fishing and reindeer herding (IWGIA, 2012; Slezkine, 1994). Russian legislation does not count the Sakha - an ethnic population of northeastern Siberia - as an indigenous community because of the size of the population and late arrival in the region (IWGIA, 2012; Lehtola, 2012). However, they are recognised internationally as these bodies advocate the right of self-identification (Corntassel, 2003; Fondahl, Filippova, \& Mack, 2015). This paper follows international norms and includes three ethnic groups in the studied Arctic villages when referring to indigenous people: Evenki,
Eveny and Sakha. The Evenki and Eveny are indigenous Tungus-speaking communities mainly populating the Arctic regions of northeastern Siberia (Fondahl et al., 2015). In the Republic of Sakha (Yakutia) they comprise $1.61 \%$ and $2.25 \%$, respectively, of the population (Rosstat, 2010). The Sakha are a Turk-speaking people widely settled in the Republic of Sakha (Yakutia) (Okladnikov, 1970; Pakendorf et al., 2006) where they migrated from southern Siberia along the Lena River at the beginning of the thirteenth century (Crate, 2008). They are a titular nation of the region and comprise $49.91 \%$ of the total population (Rosstat, 2010). In this paper, we will focus on the so-called 'northern Sakha' who essentially differ from 'southern Sakha' in their livelihood, and are culturally more similar to the Tungus people (Wixman, 1984). The northern Sakha mainly hunt reindeer, Arctic fox, sable and other fur animals, and game; fish (Arctic cisco, muksun, 
Table 1. Summary of the responses regarding climatic changes and perceived impacts on communities.

\begin{tabular}{|ll|}
\hline Changes & Perceived impact \\
\hline Winter temperature rise & Warm water regime \\
Weather unpredictability & Thawing and freezing patterns \\
Early arrival of spring & Accidents \\
Early ice break-up & Accidents \\
Late freeze-up & Winter fishing \\
Change of wind direction/strength & Change of river bed \\
Water level fluctuation & Fish quality, white fish number decrease, parasites \\
Warm water regime & Fish abundance, distribution, extinction \\
Changes in the riverbed & Fish abundance, distribution, extinction \\
Drying out of lakes & Fish abundance, distribution, extinction \\
Erosion & Remodelling of river bed \\
\hline
\end{tabular}

Siberian cisco and many others); and gather berries, such as blue berry, cowberry and cloudberry. In this study, we concentrate on fishing, which is a strong indicator of changes affecting the livelihoods of Arctic people.

\section{Results}

Arctic people's livelihoods in Yakutia are becoming increasingly vulnerable due to recent changes in climatic and environmental conditions, alongside political and economic transformations. The livelihoods in the case study areas are strongly associated with and dependent on fishing. The following three subsections look at the issues that impact local livelihoods with a focus on fishing: (1) perception of climatic and environmental changes; (2) fishing practices and changes in fish resources; and (3) regulations and policies.

\section{Climate and environmental change}

Among changes in weather patterns respondents from all four communities mentioned warmer winters, colder summers and increasing unpredictability (for the summary of changes see Table 1).

'It is warmer in winter now, which is very interesting. It was so cold in the past, that we used to start snowmobiles with a blowlamp or burnt clothes to warm the starter up' $(\mathrm{M}, 50)$.

'July used to be hot before. We used to play with the kids the entire summer... We often wore summer dress...But not now! It's getting cold, dramatically cold, and it is so windy' (F, 55).

'It is suddenly good weather, and suddenly there is a strong wind. It wasn't like that before. It is not stable now. One can never forecast what will happen when' (M, 66).

The respondents also reported the earlier arrival of spring, causing the river ice to break up earlier. Moreover, some community members observed later freezing, which hinders winter fishing.

'On the one hand, it is bad when the [winter] time arrives earlier. If it is late, the river freezes up late and it is impossible to catch a winter fish' (M, 50-60).

With regard to wind patterns, the responses are inconclusive, although most respondents noticed a change in the strength of the wind. However, some said it had become stronger, some weaker. According to the respondents the weather has become more unpredictable with changing freezing and thawing patterns of the ice negatively impacting fishing.

Members of all communities stated that river levels have essentially increased and this was a reason for fish numbers to decrease. Moreover, as one of the respondents reported:

'Fishing grounds as well as lands where we used to collect sacks of wild leek, they are all under water' (M, 51).

However, sometimes the water level in rivers is too low and threatens ship transportation. For example, in 2013, food and other commodities could not be delivered to villages along the Indigirka River for this reason. Some of the villagers have observed changes in the riverbed, which are again expected to cause a decrease in fish numbers. Lakes are reported to have dried out over recent decades, with water bodies in some areas drying out whereas in others new ones appear. This happens due to thawing of the permafrost and largely depends on the underlying soil conditions. Lakes dry up because downward percolation and evaporation are greater than the re-supply by spring snowmelt and summer precipitation, or the ground becomes water-logged due to the surface permafrost warming and the associated degradation of ground surfaces (ACIA, 2005; AMAP, 2012).

Shifting erosion and accumulation patterns remodel the riverbed and sand banks, causing fish to swim down to the river bottom. River bank erosion is due to climate change-related high water levels and permafrost thawing (ACIA, 2005). Fishers talked about river bank erosion, which means that they need to use larger nets despite this being prohibited by fishing regulations that stipulate the use of only certain types of nets.

'We used to employ seine before, but now we don't, because land is degraded, too many sandbanks, sort of islands, because water level is too low, hence we don't use seine, only nets. The land is degraded during the ice break-up, the ice forms sands and the fish goes down, therefore we have to use wide nets, 7-8-9-12 m wide. According to law one has to fish omul [Arctic 
cisco] with nets of $55 \mathrm{~mm}$ and Siberian vendace with nets of $30 \mathrm{~mm}$. If nets are bigger, then you will be fined' (M, 50).

Erosion is also a serious threat to local people's property.

\section{Fishing practices and changes in fish resources}

Participants reported a significant decrease in caught fish. If in the past one could clearly see fish under the water while rowing, nowadays it is impossible they say; the fish hide in the lower reaches of the river where it is colder or have moved further north. An interviewee reported that he could not catch a single fish during a longer time period, which upset him greatly. He reported that the fish had gone somewhere and hidden at the bottom of the river or they had not yet arrived. The only fish villagers could find in their nets were pike, a predator. Predators are - in contrast to Europe for instance - regarded as of inferior quality compared to white fish and are therefore either thrown away or given to dogs. This attitude is based on the belief that these species eat (dead) meat not only from other fish but also from drowned people. Warmer river water was highlighted as a possible factor driving fish to the bottom of a river or to the colder parts of the headstream. One of the elders said:

'We had many omul [Arctic cisco] before, one couldn't manage [with cleaning all of them], we did yukola [dried fish] but now not anymore. Why is there no fish? It's all because of the sand...the route of fish migration is blocked [by sand]' ( $\mathrm{F}, 76)$.

Residents of Chokurdakh reported catching more fish with worm infestation. In contrast, villagers from Kyusyur said that fish used to have worms but nowadays they are clean and fat. Some respondents from Chokurdakh observed Siberian salmon, which is not typical for their region and 'since it is a predator fish, it eats our broad whitefish'.

These different opinions are reflected in the quantitative survey, where the mean score for the statement 'They say the number of fish is decreasing' on a five point Likert item ( 1 for totally agree to 5 totally disagree) was 2.19 (see Table 2). This indicates that on average the respondents agree with this statement but as the value is close to neutral (3.0) with a standard deviation of 1.08 opinions do differ slightly. Interestingly, there was a significant gender gap (0.005 according to the Mann-Whitney $U$ test), where women agree more with the statement than men. However, when considering duration of residency (category 'Living > 20y' looking at residents that have lived in the area for more than 20 years irrespective of their ethnic origin) and comparing between Eveny/Evenki and Sakha ('Indigenous') there is no significant difference. Only $7.7 \%$ of men never fish, but $48.2 \%$ of women never fish. More than $40 \%$ of men fish every day or 1-2 times per week.

It becomes clear that fish are indeed rather important for indigenous people's livelihoods when looking at the statements that were below 2 on the Likert scale, which indicates an overall strong agreement (see Fig. 2).
'Fish is a very important food source for my family' (A in Fig. 2) had a score of 1.47. Obviously fish is an important protein source for Arctic families. The statement was supported ('strongly agree' and 'agree') by almost all respondents. However, indigenous people and people born in the area or resident for more than 20 years agree significantly more strongly $(\leq 0.001$ according to the Mann-Whitney $U$ test) with this statement. The same applies for 'I need to consume fish every day', which was more important to indigenous (0.006) and long-term residents $(0.007)$ than others. Both these groups fish significantly more than others $(<0.001,0.003$, respectively).

'Fishing is a traditional activity' ( $\mathrm{G}$ in Fig. 2; mean score 1.76) is also affirmed more strongly by indigenous people $(<0.001)$ and long-term residents $(0.019)$, as well as 'Fishing is being in harmony with nature' ( $\mathrm{F}$ in Fig. 2; mean score 1.62; 0.002, 0.03, respectively), and (a bit less so) 'Fishing grounds are spiritual places' (mean score 1.9; 0.054, 0.023, respectively).

The following statements were scored 2-3: 'Fishing is a relaxing activity' ( $\mathrm{C}$ in Fig. 2; mean score 2.41), 'Fish is an important income source' (D in Fig. 2; mean score 2.78), 'fishing is a good way of socialising' (H in Fig. 2; mean score 2.02), where there are no significant between-group differences, indicating that fishing is less important as a source for cash income than for subsistence.

Most men state that they always (94.3\%; see also Fig. 3) share their catch with others (nimat), while $76.5 \%$ of women - who also fish less often - do this. The same applies to long-term residents, of whom $91.7 \%$ always share, while others do this to a lesser degree (71.4\%). Despite the differences it is clear that the vast majority shares always or sometimes and only very few share rarely or never. Fig. 3 indicates a close relationship between people who share fish and those who receive fish from neighbours or relatives. However, the graph also shows that it is not a prerequisite to share fish with others in order to get fish from other people.

If they do not catch fish, most respondents always $(66 \%)$ or sometimes $(26.6 \%)$ get fish from relatives or through nimat. When asked what they do if they need fish, $36.8 \%$ give it another try, $49.5 \%$ ask friends or relatives for fish, and only $10 \%$ go to a store. The only remarkable difference is between genders, where $53.8 \%$ of men give it another try whereas only $23 \%$ of women do this, while $58.4 \%$ ask friends or relatives (men $34.7 \%$ ).

\section{Fishing regulations and policies}

The fishing regulations that were introduced after the collapse of the Soviet Union presented fishers with quotas and temporal limitations which were new to them. The quota is 'a part of total allowable catch of water bioresources' (Article 26, Federal Law No. 166-FS on fishery and the protection of water biological resources, 2004) and is allocated per person or obshchina by weight, which is not enough according to the interviewees. The 
Table 2. Quantitative results from questions asked in the survey by gender, ethnicity and long-term residency.

\begin{tabular}{|c|c|c|c|c|c|c|c|c|}
\hline Question/statement & $\begin{array}{l}\text { Answer } \\
\text { type }\end{array}$ & $n$ & Mean & Median & $\begin{array}{l}\text { Standard } \\
\text { deviation }\end{array}$ & Gender & Indigenous & $\begin{array}{l}\text { Long-term } \\
\text { resident } \\
\text { (>20 years) }\end{array}$ \\
\hline $\begin{array}{l}\text { Fish is a very } \\
\text { important food } \\
\text { source for my family }\end{array}$ & $a$ & 204 & 1.47 & 1 & 0.73 & 0.430 & $0.000^{*}$ & $0.001^{*}$ \\
\hline $\begin{array}{l}\text { I need to consume } \\
\text { fish everyday }\end{array}$ & a & 204 & 2.16 & 2 & 1.14 & 0.159 & 0.006 & 0.007 \\
\hline $\begin{array}{l}\text { Fishing is a relaxing } \\
\text { activity }\end{array}$ & $a$ & 150 & 2.41 & 2 & 1.26 & 0.370 & 0.140 & 0.080 \\
\hline $\begin{array}{l}\text { Fish is an important } \\
\text { income source }\end{array}$ & $a$ & 150 & 2.78 & 2 & 1.00 & 0.744 & 0.072 & 0.892 \\
\hline $\begin{array}{l}\text { Fishing grounds are } \\
\text { spiritual places }\end{array}$ & $a$ & 152 & 1.9 & 2 & 1.14 & 0.173 & 0.054 & 0.023 \\
\hline $\begin{array}{l}\text { Fishing is being in } \\
\text { harmony with nature }\end{array}$ & $a$ & 154 & 1.62 & 1 & 0.80 & 0.127 & $0.002^{*}$ & 0.030 \\
\hline $\begin{array}{l}\text { Fishing is a traditional } \\
\text { activity }\end{array}$ & $a$ & 153 & 1.76 & 1 & 1.07 & 0.977 & $0,000^{*}$ & 0.019 \\
\hline $\begin{array}{l}\text { Fish is a good way of } \\
\text { socialising }\end{array}$ & $a$ & 151 & 2.02 & 2 & 0.98 & 0.092 & 0.199 & 0.118 \\
\hline $\begin{array}{l}\text { They say the number } \\
\text { of fish is decreasing }\end{array}$ & $a$ & 204 & 2.19 & 2 & 1.08 & $0.005^{*}$ & 0.085 & 0.143 \\
\hline $\begin{array}{l}\text { How often do you } \\
\text { fish? }\end{array}$ & $b$ & 203 & 2.64 & 2 & 1.50 & 0.076 & 0.076 & $0.003^{*}$ \\
\hline $\begin{array}{l}\text { Do you share } \\
\text { harvested fish with } \\
\text { relatives or other } \\
\text { people? }\end{array}$ & C & 169 & 1.18 & 1 & 0.48 & $0.001^{*}$ & 0.374 & $0.001 *$ \\
\hline $\begin{array}{l}\text { Do you get fish from } \\
\text { relatives or other } \\
\text { people? }\end{array}$ & C & 203 & 1.43 & 1 & 0.67 & 0.196 & 0.204 & 0.204 \\
\hline $\begin{array}{l}\text { Which option do you } \\
\text { choose if you need } \\
\text { fish? }\end{array}$ & $d$ & 204 & 2.2 & 3 & 0.983 & $0^{*}$ & $0.003^{*}$ & 0.087 \\
\hline $\begin{array}{l}\text { How do the } \\
\text { governmental } \\
\text { fishing regulations } \\
\text { impact on your } \\
\text { livelihood? }\end{array}$ & e & 188 & 1.4 & 1 & 0.682 & 0.083 & $0^{*}$ & $0 *$ \\
\hline $\begin{array}{l}\text { If you do not catch } \\
\text { fish, what measures } \\
\text { will you take? }\end{array}$ & $f$ & 147 & 2.01 & 2 & 0.789 & $0^{*}$ & $0^{*}$ & $0^{*}$ \\
\hline $\begin{array}{l}\text { What would you do } \\
\text { with early } \\
\text { freezing-up that } \\
\text { renders fishing } \\
\text { impossible? }\end{array}$ & $g$ & 119 & 2.25 & 2 & 1.173 & $0^{*}$ & $0.004^{*}$ & 0.047 \\
\hline
\end{tabular}

*Significant at $\leq 5 \%$.

Answer type: $a=$ strongly agree (1), agree (2), neutral (3), disagree (4), strongly disagree (5); $b=$ never (1), 1-2 x a year (2), 1-2 x a month (3), 1-2 x a week (4), almost every day (4); c = always (1), often (2), rarely (3), never (4); $d$ = go fishing (1), go to store (2), ask relative/friend (3), do nothing (4); e = problematic (1), they help me (2), other (3); $f=$ fish in another area (1), wait until fish arrive (2), ask the spirits (3), other (4); $g=$ wait until it freezes (1), it is no hindrance (2), do nothing (3), other (4).

a-c are on interval scales tested with the Mann-Whitney $U$ test; $d-g$ are on ordinal scales tested with the Wilcoxon test.

weight may differ from year to year and settlement to settlement, depending on population size and many other factors. Quotas are allocated yearly by regional officials in Yakutsk. Temporal limitation means a ban of fishing for a month twice a year in spring and autumn, and thus 'make people starve' (M, 70). Most (71.3\%) of the respondents voiced the opinion that fishing regulations and policies are problematic for them, with only a minority $17.6 \%$ declaring that the regulations are helpful. Fishers stated that these regulations were established without 


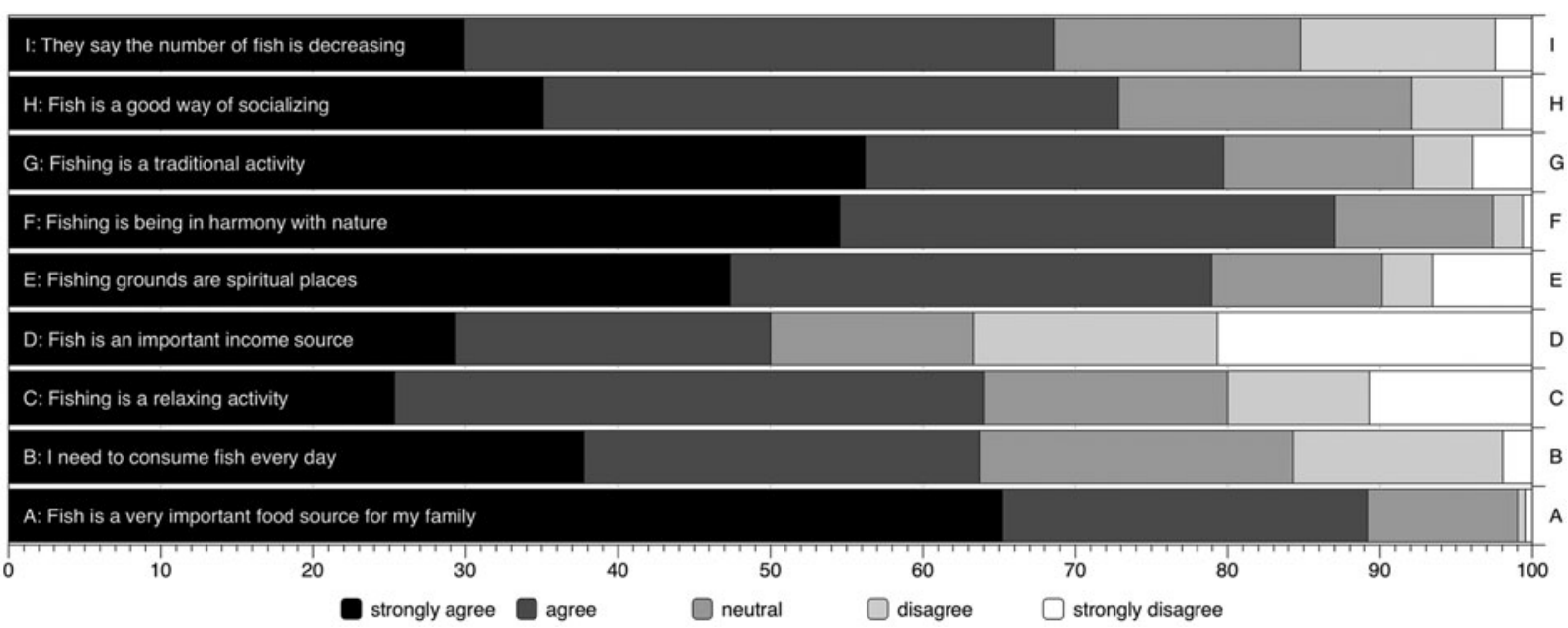

Fig. 2. Distribution of responses to statements on a Likert scale.

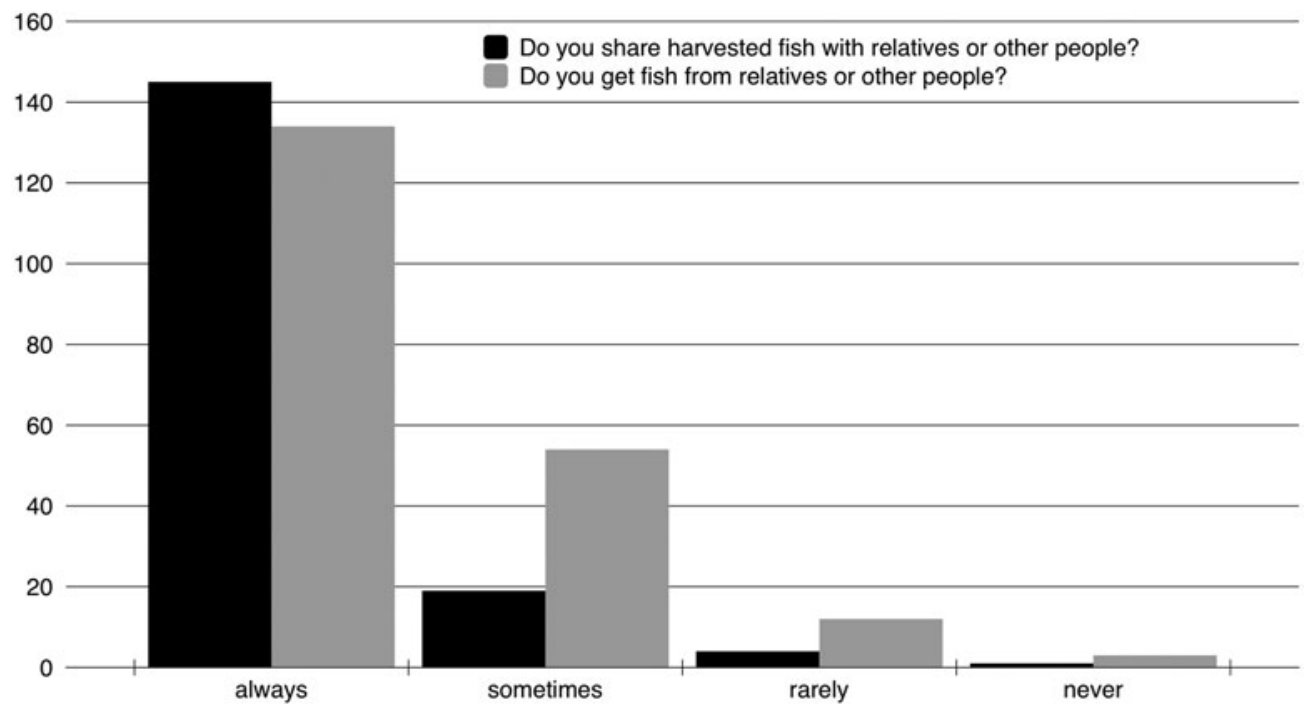

Fig. 3. Survey questions related to nimat.

taking into account conditions in the Arctic. Another concern of the local fishers was a restriction on size and type of fishing gear. According to respondents, the gear specifications are not adequate for Arctic conditions due to the size and weight of fish; therefore, people disobey regulations.

'When fishing, one must have a net of certain length, for instance maximum $25 \mathrm{~m}$, and one can't use different nets, because their length is not appropriate' (M, 53).

It is worth noting that fishing regulations are established by the Federal Government and then adapted to the local conditions by regional authorities. Yakutia belongs to the east Siberian fishery basin, hence Yakutian fishers comply with this region's rules. Moreover, there are various federal and regional programmes on fisheries development, and social and economic development of the Arctic regions that are intended to create favourable conditions for fisheries' sustainable development and thus improve quality of life. However, these are long- term programmes (until 2020) and the results are yet to come.

\section{Adaptive strategies}

Local Arctic people have been adapting to a changing environment for centuries and therefore have already developed their own coping strategies. The current adaptive strategy in the case of decreasing numbers of fish is finding new fishing grounds along the river.

'If there is no fish due to a river bed change, we move to another place where there is more fish' $(\mathrm{M}, 46)$.

However, travelling to new fishing grounds further afield may be beyond local budgets as this requires more fuel, which is expensive (from informal interviews with local fishers). Therefore, most of the respondents reported that they 'will wait until fish arrive'. In the event of a real fish shortage, fishers have to consume predator fish which, as was mentioned earlier, are regarded as being of inferior quality. However, local people have learnt how to cook 
pike or burbot cutlets from immigrants, so that these predator fish have become more popular.

The prevailing adaptive strategy to changes is outmigration. All of the research sites have been partly abandoned and most of the houses in the villages are boarded up. The village of Olenegorsk used to have a population of 800 residents before the collapse of the Soviet Union, nowadays it has only 250 people. As the villagers reported, many young adults migrate to bigger settlements in search of jobs or education. This could be related more to the social and economic situation rather than climate change. Extensive unemployment, high prices and low income force people (especially young people) to leave. In contrast, older people were against leaving their homes, even in cases of severe threat because of a deep attachment to their place of birth.

\section{Discussion}

\section{Climate change: the major stressor?}

Every system becomes vulnerable when it is susceptible to a harm caused by a single or multiple stressors (Ford \& Smit, 2004). Vulnerability can be of two origins: biophysical or social. Biophysical vulnerability is shaped by the physical event which makes the human system exposed (Brooks, 2003). Social vulnerability is determined by the social, political and economic context which contributes to exposure (Ford \& Smit, 2004). Thus, it is worth noting that Arctic communities are exposed to not only trends such as climate change, but also to socioeconomical transformations. In this section we discuss the stressors and their importance for fish resources, as well as the subsequent impacts on the livelihoods of local people.

\section{Vulnerabilities}

\section{Climatic and environmental change}

The vulnerability of the indigenous and local people has increased as a result of recent climate and environmental changes. Even though the literature suggests that climate change is a slow and long-term process with a gradual impact (Schmidt-Thome, 2013), our findings demonstrate the opposite: climatic change and its effects seem to be pronounced in the Yakutian Arctic. Increasing winter temperatures, perhaps, are favourable for indigenous and local people's survival in the harsh environment; however, it has a negative effect on their fishing practices. A warmer climate alters freezing and thawing periods. Shifts in the timing and duration of ice-related events has increased the rate of accidents for fishers and hunters in the Lower Kolyma region of Yakutia (Mustonen, 2011; Shadrin, 2009). Similarly, inhabitants of the Upernavik district in Greenland have experienced serious challenges due to late sea ice freezing. Local people used to fish halibut by long line from the ice but now fishers have to mount long lines from open dinghies (Hendriksen \& Jørgensen, 2015).

We compared respondents' concerns about increasing temperatures with meteorological records (Fig. 4; meteorological data is from KNMI (n.d.), based on the GHCN-D v2 data set). Objective data confirm that autumn temperatures are increasing. However, many respondents claim summers are getting colder, but meteorological records show the opposite. A possible explanation for perceived lower temperatures could be increased wind chill.

Climate change alters the water temperature regime, which may affect fish abundance (decrease or increase) and distribution or extinction due to the fact that fish are physiologically dependent on temperature variations (for example, for growth, reproduction, activity) (Ficke et al., 2007). Therefore, warming water bodies in the research area may negatively affect the fishing activities of the local people, and thus increase their vulnerability. Similarly, fishers in northern Norway reported the effects of warming ocean temperatures on the distribution, behaviour and type of fish caught, with fish tending to go deeper to the riverbed and large amounts of southern fish species or unknown fish being observed and caught in the region (West \& Hovelsrud, 2010).

Fluctuations in water levels affect the quality of fish, and there is a consequential decrease in the number of white fish caught. Low water levels are associated with increased parasitic infections and related problems (Reist et al., 2006). Perhaps this is a reason underlying observations of more infected fish in the research areas. Higher water levels cause floods that result in sediment input smothering macroinvertebrates and incubating fish eggs (Nilsson, Polvi, \& Lind, 2015). Local communities in Canada have also observed fluctuations in water levels. Creeks, rivers and lakes are drying out in the region, which results in a decrease of white fish numbers (Guyot, Dickson, Paci, Furgal, \& Chan, 2006).

\section{Food insecurity}

The impacts of climate change may be a serious threat to subsistence fishing, which is a critical component of the local peoples' diet. Traditional food sources are considered by local people to be more economically viable than buying in the shops; this is especially important when unemployment rates are high and wages are low (Nuttall et al., 2005). Therefore, an affordable way of making a living in the case study areas is traditional subsistence (that is, fishing, hunting). Moreover, locally sourced food is crucial for people living in remote Arctic communities (Cochran et al., 2013) where high costs of transportation fuel and other commodities may double or even triple the price. This is the case in the research area where food costs twice as much as in Yakutsk (for example, yoghurt costs 35 rubles in Tiksi, but only 17 rubles in Yakutsk).

In the face of climate change, local communities are likely to experience challenges in traditional food availability, access and distribution. This may limit the dietary intake of important nutrients such as protein, iron and zinc; of which, white fish are a rich source (Guyot et al., 2006). One of the respondents noted that his teeth were in bad condition due to the consumption 

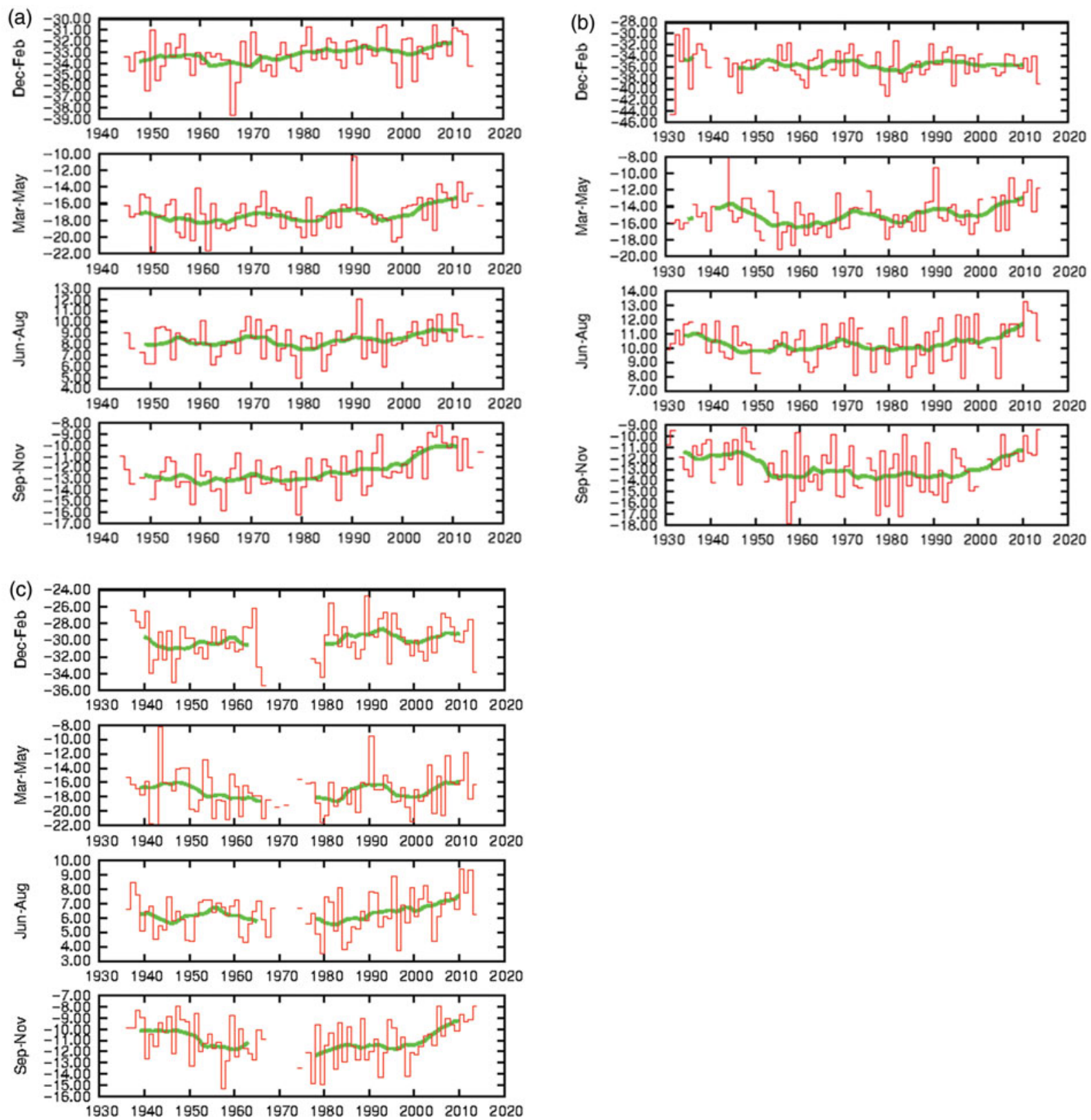

Fig. 4. Mean seasonal temperature trend recorded in (a) Chokurdakh (also applies to Olenegorsk), (b) Kyusyur and (c) Tiksi (Source: KNMI).

of 'chemicals' from a store. Furthermore, switching to a more 'western' diet increases the risk of certain diseases (for example, diabetes, obesity, cardiovascular disease) (ACIA, 2005).

Likewise, members of Inuit communities in Canada have also reported difficulties with traditional food consumption because of climatic and socio-economic stresses. Later and longer ice break-up, thinner ice, lack of pack ice during summer, higher temperatures and unpredictable weather made traditional food less available. Among socio-economic pressures, the locals cited poverty, high prices due to transportation, decline of traditional harvesting practices and increasing hunting costs (Beaumier \& Ford, 2010).

\section{Fishing policies}

Environmental variabilities tend to be harsher when they interact synergistically with political, economic and other institutions in negative ways (White, Craig Gerlach, Loring, Tidwell, \& Chambers, 2007). After the break-up of the Soviet Union, fish emerged as a very important food and income source for many people since subsidies by the communist regime ceased to support Arctic people. Fishing was more reliable and less expensive than hunting. Davydov (2014) uses the term 'free spaces' to characterise sustenance of a certain freedom of action by local people in relation to violation of fishing regulations. Local communities perceive these regulations as inappropriate and establish their own instruments to manage resources 
(Davydov, 2014). Many respondents in our study mentioned respect towards nature as a way of practicing their traditional activities, and disrespect, which is expressed in overharvesting for instance, may anger Buga and thus may deprive a fisher of luck. Therefore, rather than following official regulations local people would always follow their own unofficial (moral) rules such as harvesting only the necessary amount of resources, feeding a land's or river's spirit before fishing, being silent while harvesting and so forth.

Local people perceive regulations established by officials as uninformed of the local context (Nakhshina, 2012). During the Soviet regime the authorities usually provided local people with everything they needed, including transport and nets, because they were officially employed by the government. After the collapse, people were left alone and they had to transgress the law to survive. Interviewees emphasised the harsh climatic conditions of the Arctic, and since the legislation is designed for the entire northern Siberian region with its climatic differences, some articles of the regulations are unsuitable. For example, the spawning season of fish does not match with the fishing ban during spring or autumn in the research areas. Equally, the enforced use of smaller fishing gear is inadequate for catching big fish.

\section{Adaptive strategies}

Adaptive strategies are based on previous experiences, positive or negative, and are fundamental in face of the current challenges (Korel, 2005). Forced sedentarisation of indigenous people during the Soviet regime, separation of children from their families and growing up at residential houses broke down the continuity of generations and the passing on of traditional knowledge and adaptive strategies (Popova, 2010). In her research Popova (2003) states that children predominantly do not have a positive view of their parents' lifestyle and $78.3 \%$ of indigenous children do not want continue living in traditional ways. This means devaluation of traditions and loss of adaptive strategies that have been transferred from generation to generation (Popova, 2003). This research clearly shows that traditional knowledge of adaptive mechanisms is gradually being lost. In combination with global change, a loss of traditional knowledge about fishing and nimat decreases the potential to adequately react and increases the vulnerability of the indigenous livelihoods of Arctic peoples.

Many countries are developing various programmes on adaptive strategies with longer term perspectives. However, most rural communities think with a shortterm perspective (often out of necessity); mitigation of current risks and vulnerabilities is a higher priority than developing policies for long-term coping strategies (Schipper, Ayers, Reid, Huq, \& Rahman, 2014). Hence, governmental regulations and policies, which are limiting subsistence activities, even though they are adopted for conservation purposes, are more important than climate and environmental change or programmes of adaptive strategies.

\section{Decline of traditional knowledge}

Fishing is crucial for the social fabric of the indigenous people. Nimat as a cultural and social phenomenon tends to decline with the decrease in fishing culture resulting from climate change and restrictive fishing regulations. This may affect the whole system of the traditional culture of the indigenous people and negatively impact the most vulnerable people. Traditional knowledge and practices are passed from generation to generation. However, over recent decades, this knowledge is vanishing as a result of migration of younger people to urban areas and a reduction in the practice of traditional activities. For example, after the Soviet Union collapse, reindeer herding has been gradually declining and it is now facing great challenges. The number of domesticated reindeer in Bulunsky obshchina of Kyusyur village has decreased from 13,000 head in the late 1970 s to 2,000 . Therefore, fishing has been the only source of subsistence and a cash income for the local people. Today, Bulunsky obshchina is experiencing hard times due to loss of revenues mainly brought about by reindeer herding and credit debts. Hence, it was decided to divide the obshchina into two joint stock companies: one for fishing and the second for reindeer herding. This meant the sale of assets and, as a result, a dissolution of the obshchina, which is the backbone enterprise. In this case, this would lead to the loss of the traditional activities and cash incomes.

Traditional knowledge among young Sami people in Scandinavia is also declining due to lack of interest in schools or witnessing difficulty in conducting traditional practices such as reindeer butchering or cooking traditional food. Moreover, there are no possibilities to learn native languages in the natural setting as a result of a lack of linguistic resources or native students; therefore, indigenous languages are gradually dying out (Renvall, 2006). Native language is a means of traditional knowledge passage through vocabulary associated with animals and plants or landscape characteristics (Fondahl et al., 2015). Hence, it is tremendously important to be able to speak indigenous languages to be able to transfer traditional knowledge. In the research areas, very few interviewees could communicate in their mother tongue. For example, in the village of Olenegorsk, only about ten inhabitants out of 237 spoke the Eveny language, and they were all elders. Elders were concerned about the decline of traditional practices due to a lack of and shift of interest from younger generations as a result of harsh working conditions and low income level; hence, most of the young adults migrate to urban settlements in search of employment opportunities.

\section{Conclusions}

Fish is an important traditional food, subsistence economy and social fabric for the local people of Arctic Yakutia. 
However, over recent decades the number of caught fish has significantly decreased. Local and indigenous people attribute the decline in fish to climatic and environmental change including high water levels, increasing water temperatures and changing migration routes. However, these changes are not the only factors hindering the fishing practices of the local and indigenous people. Fishing regulations present important obstacles to the Arctic people. Local communities have developed adaptive strategies to a changing environment. While traditional adaptation of fishing techniques to seasonally changing conditions might increase the adaptation potential to future conditions under climate change, fishing regulations appear to limit this potential. Hence, we can conclude that the occurrence of the stressors of climate change, the shift from a planned to a market economy and new fishing regulations strongly increase the vulnerability of the local people. While adaptation to one stressor seems manageable, facing multiple stressors is problematic.

\section{Acknowledgements}

We are grateful for the valuable support and assistance of municipalities and local people, as well as the staff of the Institute for Biological Problems of Cryolithozone of Siberian Branch of Russian Academy of Science. We are also grateful for the Swiss Government Excellence Scholarship for Foreign Scholars for the financial support. We thank Katherine Horgan and Florian Gerber for proofreading and drawing of the maps. We would also like to express our gratitude to two anonymous reviewers for helpful feedback and inspiration.

\section{Financial support}

This research has been supported by the University of Zurich Research Priority Program on Global Change and Biodiversity.

\section{References}

ACIA. (2005). Arctic climate impact assessment. Cambridge: Cambridge University Press.

AGiP. (2015). Rybaki Yakutii oboznachili puti dlya uspeshnogo razvitiya rybokhozyastvennogo kompleksa Respubliki.

Alekseeva, E. K. (2012). Transformaciya $v$ tradicionnom pitanii tungusoyazychnyh etnosov Yakutii. Gumanitarniy Vektor, 2, 143-147.

Allison, E. H., \& Ellis, F. (2001). The livelihoods approach and management of small-scale fisheries. Marine Policy, 25, 377-388. http://doi.org/10.1016/S0308-597X(01)00023-9

AMAP. (2012). Arctic climate issues 2011: changes in Arctic snow, water, ice and permafrost. SWIPA 2011. Overview report. Oslo: Arctic Monitoring and Assessment Programme.

Anisimov, A. F. (1936). Rodovoye obshchestvo Evenkov (Tungusov). Leningrad: Izdatelstvo Instituta Narodov Severa CIK SSSR im. P.G. Smidovicha.

Article 26, Federal Law No. 166-FS on fishery and the protection of water biological resources. (2004). Moscow: Russian Federation.

Beaumier, M. C., \& Ford, J. D. (2010). Food insecurity among Inuit women exacerbated by socio-economic stresses and climate change. Canadian Journal of Public Health, 101, 196-201.

Brooks, N. (2003). Vulnerability, risk and adaptation: a conceptual framework. Norwich: Tyndall Centre for Climate Change Research.

Brown, J. D. (2011). Likert items and scales of measurement. Shiken: JALT Testing \& Evaluation SIG Newsletter, 15, 1014. Retrieved from http://jalt.org/test/PDF/Brown34.pdf

Callaghan, T. V., Tweedie, C. E., Åkerman, J., Andrews, C., Bergstedt, J., Butler, M. G., \& Zemtsov, V. A. (2011). Multidecadal changes in tundra environments and ecosystems: Synthesis of the International Polar Year-Back to the Future Project (IPY-BTF). Ambio, 40, 705-716. http://doi.org/10. 1007/s13280-011-0179-8

Cannon, T., \& Müller-Mahn, D. (2010). Vulnerability, resilience and development discourses in context of climate change. Natural Hazards, 55, 621-635. http://doi.org/10. 1007/s11069-010-9499-4

Carney, D. (2003). Sustainable livelihoods approaches: progress and possibilities for change. London: Department for International Development. Retrieved from http://www.eldis.org/vfile/ upload/1/document/0812/SLA_Progress.pdf

Caulfield, R. (2000). The political economy of renewable resource harvesting in the Arctic. In M. Nuttal \& T. Callaghan (Eds), The Arctic. environment, people, policy (pp. 485-515). Amsterdam: Harwood Academic.

Chambers, R., \& Conway, G. R. (1992). Sustainable rural livelihoods: practical concepts for the 21st century. Brighton: Institute of Development Studies, University of Sussex.

Cochran, P., Huntington, O. H., Pungowiyi, C., Tom, S., Chapin, F. S., Huntington, H. P., ... Trainor, S. F. (2013). Indigenous frameworks for observing and responding to climate change in Alaska. Climatic Change, 120, 557-567. http://doi.org/10. 1007/s10584-013-0735-2

Corntassel, J. (2003). Who is indigenous? "Peoplehood" and ethnonationalist approaches to rearticulating indigenous identity. Nationalism and Ethnic Politics, 9, 75-100. http://doi.org/10. 1080/13537110412331301365

Crate, S. A. (2008). Gone the bull of winter? Grappling with the cultural implications of and anthropology's role(s) in global climate change. Current Anthropology, 49, 569-595. http:// doi.org/10.1086/529543

Davydov, V. N. (2014). Fishery in "free spaces": non-compliance with fishery regulations in a northern Baikal Evenki village. Polar Record, 50, 1-12. http://doi.org/10.1017/ S0032247414000163

De Haan, L., \& Zoomers, A. (2005). Exploring the frontier of livelihood research. Development and Change, 36, 27-47.

DFID. (2002). Sustainable livelihoods guidance sheet. London: Department for International Development.

Ficke, A., Myrick, C., \& Hansen, L. (2007). Potential impacts of global climate change on freshwater fisheries. Reviews in Fish Biology and Fisheries, 17, 581. http://doi.org/10.1007/ s11160-007-9059-5

Fondahl, G., Filippova, V., \& Mack, L. (2015). Indigenous peoples in the new Arctic. In B. Evengard, O. Nymand Larsen, \& O. Paasche (Eds), The new Arctic (pp. 7-22). Basel: Springer.

Ford, J. D., \& Smit, B. (2004). A framework for assessing the vulnerability of communities in the Canadian Arctic to risks associated with climate change. Arctic, 57, 389400.

Forsyth, J. (1989). The indigenous peoples of Siberia in the twentieth century. In A. Wood \& R. A. French (Eds), The development of Siberia: people and resources (pp. 72-95). New York, NY: St Martin's Press. 
Geiser, U., Müller-Böker, U., Shahbaz, B., Steimann, B., \& Thieme, S. (2011). Towards an analytical livelihoods perspective in critical development research. In U. Wiesmann \& H. Hurni (Eds), Research for sustainable development: foundations, experiences, and perspectives (pp. 257-271). Bern: University of Bern, Perspectives of the Swiss National Centre of Competence in Research (NCCR) NorthSouth.

Guyot, M., Dickson, C., Paci, C., Furgal, C., \& Chan, H. M. (2006). Local observations of climate change and impacts on traditional food security in two northern Aboriginal communities. International Journal of Circumpolar Health, 65, 403-415. http://doi.org/10.3402/ijch.v65i5.18135

Hefer, B., \& Pruginin, Y. (1981). Commercial fish farming: with special reference to fish culture in Israel. New York, NY: Wiley.

Hendriksen, K., \& Jørgensen, U. (2015). Hunting and fishing settlements in Upernavik district of northern Greenland challenged by climate, centralization, and globalization. Polar Geography, 38, 123-145. http://doi.org/10.1080/1088937X. 2015.1034222

IWGIA. (2012). Briefing note. Indigenous people in the Russian Federation. Retrieved from http://www.iwgia.org/iwgia files_publications_files/0590_Indigenous_Peoples_in_the Russian Federation IGIA Briefing note March 2012.pdf

Jeffries, M. O., Overland, J. E., Brown, R., Mudryk, L., \& Luojus, K. (2015). Arctic report card, 2015. http://www.arctic.noaa. gov/reportcard, 93.

Kirillov, A. F. (2002). Promyslovye ryby Yakutii. Moscow: Nauchnyi Mir.

Kirillov, A. F. (2007). Taksonomicheskiy sostav ikhtiofauny presnyh vodoemov Yakutii. Vestnik YaGU, 4, 5-8.

Klokov, K. B., \& Khrushchev, S. A. (2010). Demographic dynamics of the indigenous small-numbered peoples of the Russian North, 1897-2002. Sibirica, 9, 41-65. http://doi.org/10.3167/ sib.2010.090303

KNMI. (n.d.). KNMI climate explorer. https://climexp.knmi.nl

Kokolova, L. M., Sofronov, V. M., Platonov, T. A., Zakharov, E. S., Verkhovtseva, L. A., \& Gavrilyeva, L. Y. (2012). Epizootologicheskaya situaciya po zoonozam i parazitarnym boleznyam zhivotnyh i ryb v Yakutii. Vestnik SVFU, 9, 86-90.

Korel, L. V. (2005). Sociologiya adaptaciy: voprosy teorii, metodologii i metodiki. Nauka. Moscow: Novosibirsk.

Lavrillier, A. (2013). Climate change among nomadic and settled Tungus of Siberia: continuity and changes in economic and ritual relationships with the natural environment. Polar Record, 49, 260-271. http://doi.org/10.1017/ S0032247413000284

Lehtola, M. (2012). HoWhy theory and the cultural transition in the Sakha Republic. In T. Äikäs, S. Lipkin, \& A. -K. Salmi (Eds.), Archeology of social relations: ten case studies by Finnish archaeologists (pp. 51-76). Oulu: Oulu University.

Investment passport. (2015). Investment passport of Allayikovskiy ulus (district) of the Republic of Sakha (Yakutia). Chokurdakh: MO "Allaikhovskiy ulus".

Moerlein, K. J., \& Carothers, C. (2012). Total environment of change: impacts of climate change and social transitions on subsistence fisheries in northwest Alaska. Ecology and Society, 17, 10.

Mustonen, T. (2011). Songs of the Kolyma Tundra. Lehtoi, Finland: Snow change cooperative City, 14.

Nakhshina, M. (2012). "Without fish, there would be nothing here": attitudes to salmon and identification with place in a Russian coastal village. Journal of Rural Studies, 28, 130138. http://doi.org/10.1016/j.jrurstud.2012.01.014
Nasledie Sela. (n.d.). Chokurdakh. Opisanie. Retreived from http: //www.nasledie-sela.ru/places/SAY/797/8527/

Nilsson, C., Polvi, L. E., \& Lind, L. (2015). Extreme events in streams and rivers in arctic and subarctic regions in an uncertain future. Freshwater Biology, 60, 2535-2546. http: //doi.org/10.1111/fwb.12477

Nuttall, M., Berkes, F., Forbes, B., Kofinas, G., Vlassova, T., \& Wenzel, G. (2005). Hunting, herding, fishing, and gathering: indigenous peoples and renewable resource use in the Arctic. New York, NY: Cambridge University Press.

Okladnikov, A. P. (1970). Yakutia before its incorporation into the Russian state. Montreal: McGill-Queen's University Press.

Pakendorf, B., Novgorodov, I. N., Osakovskij, V. L., Danilova, A. P., Protod'jakonov, A. P., \& Stoneking, M. (2006). Investigating the effects of prehistoric migrations in Siberia: genetic variation and the origins of Yakuts. Human Genetics, 120, 334-353. http://doi.org/10.1007/s00439-006-0213-2

Popova, A. G. (2003). Contemporary state of a family of indigenous small-numbered people of the north of the Republic of Sakha (Yakutia). Yakutsk.

Popova, A. G. (2010). The youth of the North: ethnic identity and the specifics of social adaptation. Severo-Vostochniy Gumanitarniy Vestnik, 1, 26-31.

Prowse, T. D., Wrona, F. J., Reist, J. D., Gibson, J. J., Hobbie, J. E., Lévesque, L. M. J., \& Vincent, W. F. (2006). Climate change effects on hydroecology of arctic freshwater ecosystems. Ambio, 35, 347-358. http://doi.org/10.1579/ 0044-7447(2006)35

Rakodi, C. (2002). A livelihoods approach - conceptual issues and definitions. In C. Rakodi \& T. Lloyd-Jones (Eds), Urban livelihoods: a people-centred approach to reducing poverty (pp. 3-22). Abingdon: Earthscan.

Regnum. (2016). V Yakutii na cenu ryby vliyayut perekupschiki, vysokiy spros i dorogaya perevozka. Retrieved from https: //regnum.ru/news/economy/2159833.html

Reist, J. D., Wrona, F. J., Prowse, T. D., Dempson, J. B., Power, M., Köck, G., ... Tallman, R. F. (2006). Effects of climate change and UV radiation on fisheries for Arctic freshwater and anadromous species. Ambio, 35, 402-410. http://doi.org/ 10.1579/0044-7447(2006)35[402:eoccau]2.0.co;2

Reist, J. D., Wrona, F. J., Prowse, T. D., Power, M., Dempson, J. B., Beamish, R. J., ... Sawatzky, C. D. (2006). General effects of climate change on Arctic fishes and fish populations. Ambio, 35, 370-380. http://doi.org/10.1579/ 0044-7447(2006)35

Renvall, E. H. (2006). Composite report on the status and trends regarding the knowledge, innovations and practices of indigenous and local communities: regional report: Arctic. Granada: Convention on Biological Diversity.

Rosstat. (2010). Vserossiyskaya perepis naseleniya. Russian Census.

Rosstat. (2016). Chislennost' postoyannogo naseleniya po municipal'nym raionam. Russian Census.

Schipper, E. L. F., Ayers, J., Reid, H., Huq, S., \& Rahman, A. (2014). Community-based adaptation to climate change: scaling it up. Abingdon: Routledge.

Schmidt-Thome, P. (2013). Climate change adaptation in practice: from strategy development to implementation. Chichester: Wiley-Blackwells.

Scoones, I. (1998). Sustainable rural livelihoods a framework for analysis. Analysis, 72, 1-22. http://doi.org/10.1057/palgrave. development.1110037

Shadrin, V. I. (2009). Korennye narody v usloviyakh izmeneniya klimata (na primere narodov Severa Yakutii). Voprosy Istorii I Kultury Severnyh Stran I Territoriy, 2. 
Sirina, A. (2012). Evenki $i$ Eveny $v$ sovremennom mire: samosoznanie, prirodopol'zovanie, mirovozzrenie. Moscow: Vostochnaya Literatura.

Slezkine, Y. (1994). Arctic mirrors: Russia and the small peoples of the North. New York, NY: Cornell University Press.

Totonova, E. E., \& Sleptsov, S. Y. (2014). Arkicheskie rayony Respubliki Sakha (Yakutia) i vozmojnosti adaptacii k rynku. Koncept, 9, 1-11.

Tugolukov, V. A., Turaev, V. A., Spevakovskiy, V. A., \& Kocheshkov, N. V. (1997). Istoriya i kultura Evenov: istorikoetnograficheskiye ocherki. Saint-Petersburg: Nauka.

Vakhtin, N. (1992). Native peoples of the Russian Far North. London.

Wedemeyer, J. (1996). Physiology of fish in intensive culture systems. New York, NY: Chapman and Halls.
West, J. J., \& Hovelsrud, G. K. (2010). Cross-scale adaptation challenges in the coastal fisheries: findings from Lebesby, Northern Norway. Arctic, 63, 338-354.

White, D. M., Craig Gerlach, S., Loring, P., Tidwell, A. C., \& Chambers, M. C. (2007). Food and water security in a changing Arctic climate. Environmental Research Letters, 2, 045018. http://doi.org/10.1088/1748-9326/2/4/045018

Wixman, R. (1984). The People of the USSR: an ethnographic handbook. New York, NY: M.E. Sharpe.

YuNN, M. (n.d.). Municipalnoe Obrazovanie "Yukagirskiy Nacionalniy Nasleg". http://ukagir.sakha.gov.ru (accessed 31 January 2017).

Ziker, J. P. (2002). Peoples of the Tundra. Northern Siberians in the post-communist transition. Prospect Heights: Waveland Press. 